\title{
Subclinical immune reactions to viral infections may correlate with child and adolescent diagnosis of attention-deficit/hyperactivity disorder: a preliminary study from Turkey
}

Mervan Bekdas', Ali Evren Tufan², İsmail Necati Hakyemez³ ${ }^{3}$ Tekin Tas ${ }^{4}$, Hüseyin Altunhan ${ }^{1}$, Fatih Demircioglu ${ }^{1}$, Erol Kismet ${ }^{1}$, Abant Izzet Baysal University Faculty of Medicine ${ }^{1}$

1. Department of Pediatrics, Bolu,Turkey

2.Department of Child and Adolescent Psychiatry, Bolu,Turkey

3.Department of Infectious Diseases and Clinical Microbiology,

Bolu,Turkey

4.Department of Medical Microbiology, Bolu,Turkey

\begin{abstract}
Background: Attention-Deficit/Hyperactivity Disorder (ADHD) is one of the most common neuro-developmental disorders of childhood and adolescence. Studies focusing on the relationship of infectious agents and ADHD are scarce. It is also known that cerebellar injury may lead to hyperactive behavior. This study aimed to evaluate the relationship between viral agents of cerebellitis and the diagnosis of ADHD.

Methods: The study group was formed of 60 consecutive ADHD patients and 30 healthy children. IgG levels for VZV; HSV-1, CMV, Measles, Mumps, Rubella and EBV were evaluated.

Results: Males were significantly higher among patients with ADHD ( $65 \%$ vs. $40 \%, \mathrm{p}=0.025)$. Patients with ADHD displayed significantly higher positivity for measles IgG $(80 \%$ vs. $60 \%, \mathrm{p}=0.044)$. When patients with ADHD were classified according to their pubertal status, adolescents with ADHD displayed higher positivity for mumps (100\% vs. $74.4 \%, \mathrm{p}=0.043)$. Most of the patients were diagnosed with ADHD-Combined or Hyperactive/Impulsive Subtypes (56.6\%) while 43.3\% were diagnosed with ADHD-predominantly inattentive type. When patients with subtypes of ADHD were compared in terms of seropositivity, it was found that patients with ADHD-Combined/ Hyperactive-Impulsive subtypes had significantly elevated reactions for Rubella ( $100 \%$ vs. $88.5 \%$, $\mathrm{p}=0.044)$.

Conclusion: Although limited to a single center and may be prone to sampling biases, our results may support the notion that immune reactions may be related with ADHD among children and adolescents. Further, prospective studies from multiple centers are needed to support our findings and establish causality.
\end{abstract}

Key words: ADHD, infection, immunology, measles, rubella, mumps, IgG

African Health Sciences 2014; 14(2):439-445

DOI: http://dx.doi.org/10.4314/ahs.v14i2.21

\section{Introduction}

Attention-Deficit/ Hyperactivity Disorder (ADHD) is one of the most important neuropsychiatric disorders of childhood and adolescence. The worldwide prevalence of ADHD is reported to be $5.3 \%{ }^{[1]}$ According to DSMIV-TR the diagnosis of ADHD requires the presence of at least 6 symptoms of inattention and/ or at least

\section{Corresponding author: \\ Mervan Bekdas \\ Abant Izzet Baysal University \\ Faculty of Medicine \\ Department of Pediatrics, Bolu-Turkey \\ Phone:+903742534656//3455 \\ merbek14@yahoo.com}

African Health sciences Vol 14 No. 2 June 2014
6 symptoms of hyperactivity/ impulsivity lasting for at least 6 months. Significant dysfunction due to symptoms must be present in at least 2 areas of daily life (i.e. peers, academic, family). The presence of at least some of the symptoms before 7 years of age is also required for this diagnosis. ${ }^{[2]}$ Approximately half of child and adolescent cases display dysfunction and continue to have symptoms in adulthood, underlining the importance of this diagnosis. ${ }^{[3]}$ ADHD is known to be highly heritable and it is known that genetic factors are important in etiology. ${ }^{[4,5]}$ However, some environmental factors are known to play a role, especially affecting the severity of symptoms and comorbidities. Vascular, toxic, metabolic, mechanical and physical causes of brain damage, especially affecting the basal ganglia are posited among environmental etiologies. ${ }^{[6]}$ Maternal use of nicotine and alcohol in the fetal period as well as 
elevated blood levels of lead in the post natal life of the infant are reported to increase risk fo ADHD. ${ }^{[7-9]}$ Among mothers of clinical samples of Turkish children and adolescents diagnosed with ADHD, presence of at least one prenatal risk factor is reported to vary between 20.5-39.3\%. ${ }^{[10-11]}$ In the same studies, the prevalence of post-natal problems were reported to be 8.1- 15.5 $\%{ }^{[10,11]}$

Studies on the relationship between prenatal infections and psychiatric diagnoses have mainly focused on schizophrenia and psychotic disorders. ${ }^{[12-14]}$ However, there are also some supports for the relationship of viral infections and ADHD. ${ }^{[15-17]}$ First of all, there are reports of seasonal patterns of births of children who would be diagnosed with ADHD and these may support an association with seasonally mediated viral infections. ${ }^{[15]}$ It was reported that exposure to viral infections during winter in first trimester of fetal life or at the time of birth may be a predisposing factor in up to $10 \%$ of patients with ADHD. ${ }^{[15]}$ Viral infections may have effects on various periods of development and infections during pregnancy, at birth and early childhood have been reported to increase risk for ADHD ${ }^{[16]}$ In a case controlled study from Italy, it was reported that infections with measles, varicella zoster virus (VZV) and rubella were reported significantly more frequently by mothers of children with $\mathrm{ADHD}$, although the rates were small $(5.6 \%$ vs $0.0 \%) \cdot{ }^{[17]}$ Human Immunodeficiency Virus (HIV) may also elevate risk of ADHD while antibodies to Herpes Simplex virus (HSV) were not found to correlate with ADHD. ${ }^{[18]}$ It is also known that febrile seizures may increase risk of ADHD and that they may be associated with Human herpesvirus 6 (HHV 6) or influenza viruses. ${ }^{[19]}$ Tuberculosis meningitis, enterovirus 71 and coxackie virus are also studied in terms of their relationship with ADHD. ${ }^{[20-22]}$

Cerebellum may play a role in ADHD in terms of its importance in motor as well as cognitive functions. ${ }^{[23,24]}$ It is also known that postnatal infections, especially in infancy may lead to hyperactivity. ${ }^{[25]}$ Inflammation of the cerebellum in childhood may be infectious, postinfectious or due to vaccines. ${ }^{[25-35]}$ Infectious agents may also be varied. Some of the patients may be asymptomatic through infection or may display only mild symptoms. ${ }^{[25-35]}$ Therefore, we aimed to determine the relationships of measles, mumps, rubella, cytomegalovirus (CMV), Ebstein- Barr Virus (EBV), HSV and VZV, which may all be agents of cerebellar inflammation, to ADHD. ${ }^{[25-35]}$ As far as we are aware, no controlled studies on Turkish children and adolescents with ADHD to determine their status of immunity to viral agents have been conducted up to now.

\section{Material and Methods Participants}

The records of 6074 patients who were referred to the outpatient clinic of Child and Adolescent Psychiatry Department at the study center between October 2011 and October 2012 were screened for their presenting complaints and those applying for "inattention" and "hyperactivity" were recorded. It was found that 332 patients were referred for those two complaints and received initial diagnoses of ADHD or ADHD-Not Otherwise Specified (NOS). A second review for missing data resulted in 164 patients. After exclusion of patients with ADHD-NOS, 78 patients with ADHD (Combined, Predominantly Hyperactive/ Impulsive and Predominantly Inattentive Subtypes) were selected. The patients were divided into children and adolescents according to their age ( $<11$ years) and pubertal status in physical evaluations.

To be eligible for ADHD the patients should be diagnosed with semi-structured interviews conducted by residents or an experienced child and adolescent psychiatrist according to DSM-IV-TR criteria and Mental Retardation (MR) should be ruled out with Wechsler Intelligence Scale for Children-Revised where appropriate or with clinical interviews. MR was defined as per DSM-IV criteria (i.e. IQ $<70$ along with dysfunction in at least 2 areas of functioning). Patients who were diagnosed in the interview with ADHD according to DSM-IV-TR and DSM-IV-Based Child and Adolescent Behavioral Disorders Screening and Rating Scale (T-DSM-IV-S) criteria formed the ADHD group. Patients younger than 7 years and those older than 18 years, those with comorbid MR, Autistic Spectrum Disorders and psychotic disorders as well as patients with chronic physical/ neurological disorders were excluded from the study. Thirty healthy patients who were being followed up within the same period at the Pediatrics Department formed the control group. A pediatric evaluation and interview with children and family members helped rule out psychopathology in this group. A child and adolescent psychiatrist ruled out presence of psychopathology.

Children and adolescents with ADHD were free to continue their treatments during the study period. All of the study procedures were in accordance with the Declaration of Helsinki and local laws and regulations. 
The Institutional Board of Ethics approved of the study protocol and informed consent was procured from the parents as well as the assent of children and adolescents. Eighteen of the patients with ADHD were excluded due to parental refusal of participation or based on the exclusion/inclusion criteria.

\section{Measures/instrumentation}

Turgay DSM-IV-Based Child and Adolescent Behavioral Disorders Screening and Rating Scale (T-DSM-IV-S): This scale was developed by Turgay and measures disruptive behavioral problems based on DSM-IV diagnostic criteria. ${ }^{[36]}$ It was translated to Turkish by Ercan. ${ }^{[3]}$ T-DSM-IV-S is also a four-point Likert-type scale. Nine items in this scale assess severe hyperactivityimpulsivity, 9 items assess attention-deficit, 8 items assess oppositional behavior, and 15 items assess symptoms of conduct disorder. It is completed by parents in the current study.

Wechsler Intelligence Scale for Children-Revised (WISC-R): The WISC-R was designed to measure the IQ of the children between the ages of 6 and $16 \cdot{ }^{[38,39]}$ The standardization of the WISC-R for Turkish children was conducted by Savaşır and Şahin. ${ }^{[38]}$ For the 16- 17 year old group MR was ruled out by developmental history along with Similarities and Digit Symbol-Coding subtests of Wechsler Adult Intelligence Scale.

\section{Procedures}

The study was approved by the Abant Izzet Baysal University Ethics Committee. The parents who agreed to take part were provided with patient information sheet, outlining the research protocol and provided written informed consent. Oral assent was also procured from all of the children. Initially, all children were interviewed by a child and adolescent psychiatrist and ADHD diagnoses were made according to the DSMIV-TR criteria. Parents completed the T-DSM-IV-S. When the clinicians deemed it necessary, WISC-R was also used to rule out MR. The tests were administered by an expert psychologist who had specific training and experience regarding the administration.

IgG levels for rubella, EBV, HSV1, CMV (DIA.PRO (Milano, Italy)) and measles, mumps, VZV (NovaTec (Dietzenbach, Germany)) were evaluated from the plasma via micro-ELISA method. Fasting blood was drawn in the morning, prior to stimulant use in children with ADHD. The analyzing laboratory was blind to diagnostic status.

\section{Statistical Analyses}

The records of patients were entered into a database prepared with Statistical Package for Social Sciences for Windows ${ }^{\mathrm{TM}}$ Version 15.0 (SPSS, SPSS Inc., Chicago, IL.). Descriptive, Mann-Whitney U and Student's t tests were used in analyses. Nominal data were compared in between groups with Chi-Square test and Fisher's correction was used as needed. Descriptive analyses were used for summarizing data. P-value significance was set at 0.05 .

\section{Results}

Within the study period 60 patients with ADHD were enrolled in the study. The patients with ADHD were mostly male $(n=39,65 \%)$. Seropositivity in the ADHD group for viral agents was frequent with rubella and CMV being most frequent ( $\mathrm{n}=57,95 \%$; each). It was found that males and those with elevated measles IgG were significantly higher among patients with ADHD ( $p=0.025$ and 0.044 ; respectively). Comparisons between ADHD and control groups in terms of seropositivity are summarized in Table 1.

Table 1: Comparison of Turkish children and adolescents with ADHD and healthy controls in terms of immune status for viral agents

\begin{tabular}{llll}
\hline & ADHD & Controls & p value \\
& $(\mathbf{n}=\mathbf{6 0 )}$ & $\mathbf{( n = 3 0 )}$ & \\
\hline Age $^{1}$ (years) & $9.0(2.2)$ & $9.8(2.9)$ & 0.16 \\
Male* $_{\text {Rubella IgG* }}$ & $39(65)$ & $12(40)$ & 0.025 \\
EBV IgG* & $57(95)$ & $28(93.3)$ & 0.74 \\
CMV IgG* & $57(95)$ & $25(83.3)$ & 0.83 \\
HSV-1 IgG* & $38(63.3)$ & $24(80)$ & 0.1 \\
VZV IgG* & $54(90)$ & $26(86.7)$ & 0.63 \\
Mumps IgG* & $48(80)$ & $23(76.7)$ & 0.71 \\
Measles IgG* & $48(80)$ & $18(60)$ & 0.044 \\
\hline
\end{tabular}

$\left({ }^{1}:\right.$ Mean $\left.(\mathrm{SD}),{ }^{*}: \mathrm{n}(\%)\right)$

It was observed that 13 patients $(21.6 \%)$ were in adolescence while the rest were children. The proportions of males were $84.6 \%$ among adolescents and $59.5 \%$ among children. All of the adolescents were seropositive for mumps while $74.4 \%$ of children were positive. Comparison of adolescents and children with ADHD diagnosis revealed that positive mumps IgG was significantly higher among adolescents with ADHD $(p=0.043)$. No other differences could be found between 
children and adolescents diagnosed with ADHD (Table 2).

Table 2: Comparison of Turkish children and adolescents with ADHD in terms of immune status for viral agents (ADHD-Ch: Children diagnosed with ADHD (i.e. $<11$ years), ADHD-Ad: Adolescents diagnosed with ADHD ( $\geq 11$ years))

\begin{tabular}{llll}
\hline Variables & $\begin{array}{l}\text { ADHD-Ch } \\
(\mathrm{n}=47)\end{array}$ & $\begin{array}{l}\text { ADHD-Ad } \\
(\mathrm{n}=13)\end{array}$ & $\mathrm{p}$ value \\
$\mathrm{n}(\%)$ & $28(59.5)$ & $11(84.6)$ & 0.098 \\
\hline Male & $46(97.8)$ & $11(84.6)$ & 0.054 \\
Rubella IgG & $41(87.2)$ & $10(76.9)$ & 0.36 \\
EBV IgG & $46(97.8)$ & $13(100)$ & 0.59 \\
CMV IgG & $29(61.7)$ & $9(69.2)$ & 0.62 \\
HSV-1 IgG & $42(89.3)$ & $12(92.3)$ & 0.75 \\
VZV IgG & $35(74.4)$ & $13(100)$ & 0.043 \\
Mumps IgG & $37(78.7)$ & $11(84.6)$ & 0.64 \\
Measles IgG & 37 \\
\hline
\end{tabular}

When subtypes of ADHD were evaluated, it was found that patients in our study center were mostly of inattentive (IA, $n=26,43.3 \%)$ and combined $(C, n=24$, $40 \%$ ) types with only 10 patients (HI, $n=16.6 \%)$ being diagnosed with predominantly hyperactive/impulsive type. Because of the importance of cerebellum in motor functions, we combined ADHD-combined and ADHD- predominantly hyperactive/impulsive types $(\mathrm{n}=34,56.6 \%)$ and compared them with ADHD- inattentive type in terms of seropositivity. The comparison of subtypes revealed that all of the patients with ADHD-C and ADHD-HI were positive for rubella IgG while only $88.5 \%$ ( $n=23$ ) of ADHD-IA were positive. This difference was statistically significant $(\mathrm{p}=0.044)$. No other differences in seropositivity were found (Table 3).

Table 3: Comparison of Turkish children and adolescents with ADHD subtypes in terms of immune status for viral agents (ADHD-C: ADHD-Combined Type, ADHD-HI: ADHD-Hyperactive/ Impulsive Type, ADHD-IA: ADHD Inattentive Type)

\begin{tabular}{|c|c|c|c|}
\hline $\begin{array}{l}\text { Variables } \\
\text { n (\%) }\end{array}$ & $\begin{array}{l}\text { ADHD-C and } \\
\text { HI } \\
(n=34)\end{array}$ & $\begin{array}{l}\text { ADHD-IA } \\
(n=26)\end{array}$ & p value \\
\hline Male & $21(61.8)$ & $18(69.2)$ & 0.55 \\
\hline Rubella IgG & $34(100)$ & $23(88.5)$ & 0.044 \\
\hline EBV IgG & $29(85.3)$ & $22(84.6)$ & 0.94 \\
\hline CMV IgG & $34(100)$ & $25(96.2)$ & 0.25 \\
\hline HSV-1 IgG & $21(61.8)$ & $17(65.4)$ & 0.77 \\
\hline VZV IgG & $30(88.2)$ & $24(92.3)$ & 0.6 \\
\hline Mumps IgG & $26(76.5)$ & 22 (84.6) & 0.43 \\
\hline Measles IgG & $27(79.4)$ & $21(80.8)$ & 0.89 \\
\hline
\end{tabular}

\section{Discussion}

This study aimed to determine seropositivity among consecutive pediatric patients with ADHD at a tertiary treatment center and compare it with healthy controls. As a result, it was found that patients with ADHD displayed significantly higher positivity for Measles IgG, that children with ADHD displayed significantly higher seropositivity for Rubella while adolescents with ADHD displayed higher positivity for mumps and that patients with ADHD-Combined/Hyperactive- 
Impulsive subtypes had significantly elevated reactions for Rubella.

The diagnosis of ADHD is known to display male preponderance, especially in clinical populations. ${ }^{[40-42]}$ This preponderance was posited to be due to differing presentations of the disorder. Girls with ADHD predominantly display symptoms of inattention as well as internalizing disorders while boys predominantly display externalizing symptoms requiring applications to clinics. ${ }^{[41]}$ In accordance with the literature, males were more frequent in our sample of patients with ADHD (65\%).

Immune status of patients with ADHD in terms of viral agents have received limited attention up to now and measles is no exception to this trend. Arpino and colleagues reported that $\mathrm{ADHD}$ is more frequently diagnosed among offspring of mothers who contracted measles during pregnancy. ${ }^{[17]}$ Measles seropositivity was also significantly higher among our sample with ADHD, especially if motor hyperactivity was part of the picture. It is known that infection during pregnancy may be risk factor for psychopathology among offspring. This risk seems to be associated with Toxoplasma gondii, rubella, HSV-2 and influenza. In schizophrenic patients an association between rubella, VZV, measles, CMV and autistic symptoms has also been reported. Besides, VZV, rubella, HIV, HHV-6, influenza, enterovirus 71 , and coxackie viruses as well as M. Tuberculosis and T. gondii have been implicated in ADHD. ${ }^{[12,18-22]}$ Infections and immune activation are also implicated in other childhood psychiatric disorders such as Obsessive Compulsive Disorder, Tourette's Disorder and PANDAS (Pediatric Autoimmune Neuropsychiatric Disorders Associated with Streptococci). ${ }^{[12]}$

Although exact mechanisms are still not known several mechanism may be posited on the relationship of viral infections and risk of ADHD. Firstly, Major Histocompatibility Complex (MHC) proteins may be involved. MHC-Class I proteins are also produced by neurons and nerve cells may use MHC for communication. They may also be involved in synaptic plasticity during embryonic development and in formation of reciprocal connections between brain and eyes. Rodents with MHC deficiencies were shown to display learning deficits. Secondly, infection leads to elevations of IL-1 and 6 and stimulation of vagus nerves, which in turn, stimulates CNS to increase IL-1 and 6 and activate microglia. Cytokines may interact with MHC to affect learning and memory. They are also reported to change activities of monoamine transporters and change synaptic structures. ${ }^{[12]}$ Alternatively, all of those mechanisms may play a role in interaction with genetic polymorphisms. Future, prospective studies on samples of children and adolescents with ADHD may clarify these issues.

Regardless of exact mechanism, our results may support the notion that pre-postnatal infections as well as vaccinations with measles may be important for ADHD. ${ }^{[43,44]}$ Zeegers and colleagues reported that ADHD-HI is the most common type (38\%), followed by ADHD-IA (26\%) among HIV-infected SouthAfrican children while other studies of seropositivity among children with ADHD generally do not report subtypes. ${ }^{[45]}$ In our sample, the most common diagnosis was ADHD-IA (43.3\%), followed by ADHD-C (40\%). This discrepancy may be due to sampling bias.

The main limitations of our study were the limited sample size from a single center, focusing on a clinical population with ADHD and its cross-sectional nature. The cross-sectional nature of the study precludes us from making assumptions of causality although we tried to posit some hypotheses on the relationship of viral infections and ADHD. Also, the number of comparisons were high for a limited sample and may be affected by Type I errors. Regardless of limitations, or results may show that viral agents especially involving cerebellum may play a role in motor hyperactivity in children and adolescents with ADHD. Future, prospective studies on larger populations conducted at multiple centers may reveal causality.

\section{Acknowledgment}

Competing interests: The authors declare that they have no competing interests in relation to this manuscript. Funding: This study was supported by the Abant Izzet Baysal University Scientific Research Foundation.

\section{References}

1. Polanczyk G, Lima MS, Horta BL, Biederman J, Rohde LA. The Worldwide Prevalence of ADHD: A Systematic Review and Metaregression Analysis Am J Psychiatry 2007;164:942-948

2. American Psychiatric Association: Diagnostic and Statistical manual of Mental Disorders, Fourth Edition, Text Revision. Washington, DC, American Psychiatric Association, 2000

3. Kessler RC, Adler L, Barkley R, Biederman J, Conners CK, Demler O, Faraone SV, Greenhill LL, Howes MJ, Secnik K, Spencer T, Ustun TB, Walters EE, Zaslavsky AM. The prevalence and correlates of adult ADHD in the United States: results from the National Comorbidity Survey Replication. Am J Psychiatry 2006; 163: 716-23 
4. Biederman J, Faraone SV. Current concepts on the neurobiology of attention-deficit/hyperactivity disorder. J Atten Disord 2002;6(suppl 1):S7-S16

5. Bridge Denckla M. ADHD: topic update. Brain Dev 2003;25:383-389

6. Sadock BJ, Sadock VA.Kaplan \& Sadock's Concise Textbook of Child and Adolescent Psychiatry.Wolters Kluwer/Lippincott Williams \& Wilkins, 2009; Chapter 7: 80

7. Braun JM, Kahn RS, Froelich T, Auinger P, Lamphear BP. Exposures to environmental toxicants and attention deficit hyperactivity disorder in U.S. children. Environ Health Perspect. 2006;114(12):1904-1909

8. Linnet KM, Daisgaard S, Obel C, et al. Maternal lifestyle factors in pregnancy risk of attention deficit hyperactivity disorder and associated behaviors: review of the current evidence. Am J Psychiatry. 2003;160(6):1028 -1040

9. Goodlad JK, Marcus DK, Fulton JJ. Lead and Attention-Deficit/Hyperactivity Disorder (ADHD) symptoms: A meta-analysis. Clin Psychol Rev. 2013 Apr;33(3):417-25. doi: 10.1016/j.cpr.2013.01.009. Epub 2013 Jan 29

10. Senol S. Dikkat Eksikliği Y1kıc1 Davranıs Bozukluklarının klinik özellikleri, aynı grup ve diğer DSM-IV tanılarıyla birliktelikleri, risklerin ve tedavi eğiliminin belirlenmesi. (Uzmanlık Tezi). Ankara: Gazi Üniversitesi; 1997.

11. Yolga Tahiroğlu A. Dikkat Eksikliği Hiperaktivite Bozukluğu tanısı alan çocukların sosyodemografik Özellikleri, eslik eden bozukluklar ve tedavi yaklasımları. (Uzmanlık Tezi). Adana: Çukurova Üniversitesi; 2003.

12. Patterson PH. Infectious Behavior: Brain- Immune connections in Autism, Schizophrenia and Depression. The MIT Press, Cambridge, Mass. 2011

13.Pedersen MG, Stevens H, Pedersen CB, NørgaardPedersen B, Mortensen PB. Toxoplasma Infection and Later Development of Schizophrenia in Mothers. Am J Psychiatry 2011; 168:814-821.

14.Brown AS, Derkits EJ. Prenatal Infection and Schizophrenia: A Review of Epidemiologic and Translational Studies. Am J Psychiatry 2009; 167:261280.

15.Mick E, Biederman J, Faraone SV. Is season of birth a risk factor for attention-deficit hyperactivity disorder? J Am Acad Child Adolesc Psychiatry 1996; 35(11) : 1470-1476

16. Millichap JG. Attention Deficit Hyperactivity Disorder Handbook: A Physician's Guide to ADHD. Second Edition, Springer New York 2010; 16
17.Arpino C, Marzio M, D’Argenzio L, Longo B, Curatolo P. Exanthematic diseases during pregnancy and attention-deficit/hyperactivity disorder (ADHD). Eur J Paediatr Neurol 2005; 9(5) : 363-365

18. Sylvester Jørgensen O, Veilsgaard Goldschmidt V, Faber Vestergaard B. Herpes simplex virus (HSV) antibodies in child psychiatric patients and normal children. Acta Psychiatr Scand 1982; 66(1) : 42-49

19. Pineda DA, Palacio LG, Puerta IC, et al. Environmental influences that affect attention deficit/ hyperactivity disorder: study of a genetic isolate. Eur Child Adolesc Psychiatry 2007; 16(5) : 337-346

20. Gau SS, Chang LY, Huang LM, Fan TY, Wu YY, Lin TY. Attention-deficit/hyperactivity-related symptoms among children with enterovirus 71 infection of the central nervous system. Pediatrics 2008;122(2):e452-8 21. Chu PY, Tsai YL, Chen HL, Ke GM, Hsu CY, Chen YT, Wang CF, Su HJ, Chou LC, Hsu LC, Lin KH. Coxsackievirus B4 in southern Taiwan: molecular epidemiology. J Clin Virol. 2009 May;45(1):16-22

22. Wait JW, Stanton L, Schoeman JF.Tuberculosis meningitis and attention deficit hyperactivity disorder in children. J Trop Pediatr 2002; 48(5): 294 - 299

23.Berquin PC, Giedd JN, Jacobsen LK, Hamburger SD, Krain AL, Rapoport JL, Castellanos FX. Cerebellum in attention-deficit hyperactivity disorder: a morphometric MRI study. Neurology. 1998; 50 (4): 1087-93

24. Paule MG, Rowland AS, Ferguson SA ve ark. (2000) Attention deficit/hyperactivity disorder: characteristics, interventions, and models. Neurotoxicol and Teratol, 22:631-651

25.Fenichel GM. Clinical Pediatric Neurology- A signs and symptoms approach. Philadelphia, PA: WB Saunders Company; 1993

26.Bakshi R, BatesVE, Kinkel PR, Mechtler LL, Kinkel WR. Magnetic resonance imaging findings in acute cerebellitis. Clin Imaging 1998;22:79-85

27. Barkovich AJ. Infections of the nervous system. In: Barkovich AJ, ed. Pediatric Neuroimaging. Philadelphia, PA:Lippincott-Raven; 1996:569-617

28. Montenegro MA, Santos SL, Li LM, Cendes F. Neuroimaging of acute cerebellitis. J Neuroimaging 2002;12:72-4

29. Lishman WA. (2003) Intracranial Infections. In: Organic Psychiatry: The Psychological Consequences of Cerebral Disorder. Third Edition. Pp. 346-365, Blackwell Science, ISBN 0-86542-842-5, Oxford

30. Shoji H, Hirai S, Ishikawa K, et al. CT and MRI imaging of acute cerebellar ataxia. Neuroradiology 1991; 33: 360-361

31. Najda-Stanislawska E. Mumps cerebellitis. Eur 
Neurol 2000; 43:117

32. Manto MU, Pandolfo M. The cerebellum and its disorders. In:Other infectious disease (Cerebellitis). Cambridge University Press 2002:248-257

33. Ito H, Sayama S, Irie S, et al. Antineuronal antibodies in acute cerebellar ataxia following Epstein-Barr virus infection. Neurology 1994; 44: 1504-1507

34. Ciardi M, Giacchetti G, Fedele CG, Tenorio A, Brandi A, Libertone R, Ajassa C, Borgese L, Delia S. Acute cerebellitis caused by herpes simplex virus type 1. Clin Infect Dis. 2003 Feb 1;36(3):e50-4

35. Dangond F, Engle E, Yessayan L, Sawyer MH. Preeruptive Varicella cerebellitis confirmed by MRI. Pediatr Neurol 1993; 9:491-493

36. Turgay A. Disruptive behavior disorders child and adolescent screening and rating scale for children, adolescents, parents, and teachers. West Blomfield (Michigan), Integrative Therapy Institute Publication; 1994

37. Ercan ES, Amado S, Somer O, Çıkoğlu S. Development of a test battery for the assessment of attention deficit hyperactivity disorder. Turkish J Child Adolesc Psychiatry 2001; 8, 132-144. (In Turkish) 38. Savaşır I, Şahin N (1995) Manual for the Wechsler Intelligence Scale for Children-Revised (WISC-R).
Turkish Pscyhology Association Publication, Ankara (in Turkish)

39. Wechsler D (1974) WISC-R Manual for the Wechsler Intelligence Scale for Children-Revised. Psychological Corporation, New York

40.Gross-Tsur V, Shaley RS, Amir N. Attention deficit disorder:association with familial-genetic factors. Pediatr Neurol. 1991;7(4):258 -261

41.Spetie L, Arnold EL. Attention Deficit Hyperactivity Disorder, In:Martin A, Fred RW (eds), Lewis's Child and Adolescent Psychiatry, A Comprehensive Textbook, Philadelphia:Williams\&Wilkins, 2007: 430-54

42.Faraone SV, Biederman J, Mick E, et al. Family study of girls with attention deficit hyperactivity disorder. Am J Psychiatry. 2000;157(7):1077-1083

43.De Bruecker Y, Claus F, Demaerel P, Ballaux F, Sciot $\mathrm{R}$, Lagae L, et al. MRI findings in acute cerebellitis. Eur Radiol 2004;14:1478-83

44.Yazbak FE, Yazbak K. Live virus vaccination near a pregnancy: flawed policies, tragic results. Medical Hypothes 2002;59(3):283-288

45.Zeegers I, Rabie H, Swanevelder S, Edson C, Cotton $\mathrm{M}$, vanToorn R.Attention deficit hyperactivity and oppositional defiance disorder in HIV-infected South African children. J Trop Pediatr 2010; 56(2): 97 - 102 